\title{
Modelling hydrological changes in coastal catchments of New South Wales under future climate change
}

\author{
John Young ${ }^{1}$, Mark Littleboy ${ }^{1}$, Jocelyn Dela-Cruz ${ }^{1}$, Joel Rahman $^{2}$ and $^{\text {Xihua Yang }}{ }^{1}$ \\ ${ }^{1}$ NSW Office of Environment and Heritage, PO Box 445, Cowra NSW 2794 \\ ${ }^{2}$ Flow Matters Pty Ltd, PO Box 272 Jamison ACT 2614 \\ Email:john.young@environment.nsw.gov.au
}

\begin{abstract}
The aim of the present study was to assess the impacts of climate change on surface water runoff and groundwater recharge along coastal catchments of New South Wales (NSW). Surface flow and groundwater recharge projections can assist decisions on adaptation options for managing water resources, water quality and waterway health issues that affect the ecosystem services that our state's waterways provide. Adaptation options, for example could be to apply more water sensitive approaches (e.g. stormwater harvesting, sewer mining) to urban development in (southern NSW) catchments where projections indicate there will be more water available as surface runoff in both near-future (2020-2039) and far-future (20602079) projections.
\end{abstract}

We used the NARCliM (NSW / ACT Regional Climate Modelling) ensemble of climate projections for south-east Australia. This ensemble is designed to provide robust projections that span the range of likely future changes in climate (Evans et al., 2014). NARCliM projections over three climate epochs were used as inputs to a water balance model, PERFECT (Littleboy et al., 1992). The three epochs consisted of a baseline 1990-2009, near-future 2020-2039 and far-future 2060-2079 scenarios. PERFECT is a daily time-step, one dimensional model that predicts surface runoff, infiltration, soil evaporation, transpiration, profile drainage and groundwater recharge. We specifically modelled changes to surface flow and groundwater recharge using the $10 \mathrm{~km}$ resolution for climatic data available from NARCliM and finer resolution spatial data available for land use, foliage cover and soils across the coastal catchments of NSW.

Raster format spatial data, maps and graphs from this modelling form part of the NSW Climate Impact Profile to assess projected biophysical changes across the State. Maps show central estimates or arithmetic means of near and future projections. Bar graphs are used to present projections as ranges of plausible change, illustrating the projections from the twelve individual simulations as well as the central estimate.

Using a multi-model ensemble approach, the results of the near and future climate scenarios where compared with baseline 1990-2009 epoch to provide changes in surface runoff and groundwater recharge. The mean annual recharge averaged over the coastal catchments for near-future (2020-2039) scenario shows less recharge across much of the coast. Spatially, considerably less recharge is likely in areas along the higher parts of the Great Dividing Range (Canberra, Tamworth). For some areas along the coastal fringes (Eden to Batemans Bay, Sydney to Byron Bay), a slight increase in recharge is shown but these increases are relatively small. In the far future, recharge is expected to slightly increase across most parts of the coastal regions. Coastal fringes from Port Macquarie to Bryon Bay show a much higher increase. Some areas along the Great Dividing Range are likely to experience less recharge to groundwater. The largest impact spatially is the dramatic reduction in recharge in alpine areas.

Across much of the coastal regions, surface runoff is projected to increase slightly in both the near and far future. Largest increases are evident in the far future, in the regions from Newcastle, Port Macquarie to Byron Bay. Largest reductions in surface runoff are projected in higher ranges towards the south of the state near Canberra, and areas of the Great Dividing Range near Tamworth.

Keywords: $\quad$ Climate change, hydrology modelling, soil water balance, PERFECT, NARCliM 
Young et al., Modelling hydrological changes in Coastal catchments of New South Wales under future climate change

\section{INTRODUCTION}

Effects of climate change on the hydrological cycle has become an area of research priority, and will be one of the most vital issues for the future (IPCC 2013). The New South Wales Office of Environment and Heritage $(\mathrm{OEH})$, has previously studied the impacts of global climate change projections on the hydrology across NSW at broad scale resolution. Providing scientific information on potential future change in the hydrological cycle enables informed policy decisions and adaptation strategies (http://climatechange.environment.nsw.gov.au/).

The aim of this present study was to provide projections of potential impacts of climate change on surface flow and groundwater recharge in coastal catchments of NSW. Such projections are needed in current statewide initiatives for managing water resources and waterways. For example, climate change (over the next $50 \mathrm{y}$ ) has been identified by the Marine Estate Management Authority as a key threat to the environmental, social and economic benefits communities derive from the states coastal waterways (BMT WBM Pty Ltd, 2015). Climate driven changes to freshwater inflows were specifically identified in this initiative.

This paper describes the application of the water balance model PERFECT (Littleboy et al., 1992) using spatially specific key input drivers of land use, foliage protection cover, soils, and the NSW / ACT Regional Climate Modelling (NARCliM) ensemble of climate projections for south-east Australia (Evans et al., 2014). We present near future (2020-2039) and far future (2060-2079) projections of annual and seasonal surface runoff and recharge in comparison to baseline (1999-2009) period for a high emissions scenario - the A2 scenario from the Special Report on Emission Scenarios (SRES) of Nakicenovic et al., (2000). Changes under lower emissions are likely to be similar in nature but weaker in magnitude than these projections. Also, changes outside those contained in the NARCLIM projections are also possible.

The major limitation to the current modelling is that the NARCliM ensemble daily time-step data is available only at $10 \mathrm{~km}$ resolution. The use of finer resolution land use, foliage projected cover and soils at a resolution of $100 \mathrm{~m}$ permitted spatial variability across landscapes to be considered. The outcomes of this modelling approach are currently being considered for use in local scale catchment models (e.g. eWater Source) to provide projections of climate driven changes to runoff quality in selected priority Coastal catchments in NSW (Dela-Cruz et al., in prep).

\section{COASTAL NSW (STUDY AREA)}

The study area (Figure 1) extends along the east coast of NSW, from the Victorian border in the south to the Queensland border in the north and covers an area of more than $130,000 \mathrm{~km}^{2}$.

These coastal catchments include a diversity of inland habitats such as dune swamps, estuarine and upland lakes, endangered ecological communities (EEC) and lagoons and the health of these ecosystems reliant on either flooding events, recharge to groundwater and/or surface water runoff.

There is diverse topography across the catchments; inclusive of extensive land use (irrigation, horticulture, high density urban and rural settlements), large expanses of the Great Diving Range, and significantly varying in landforms, slope and soil types from heavy clays, acid sulphate to earthy sands.

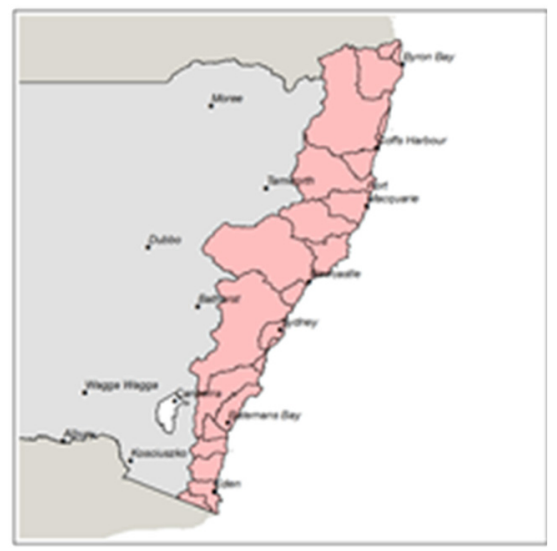

Figure 1. Coastal catchments of NSW

The study area spans 3 distinct physiographic provinces (Pain et al., 2011); New England-Moreton Uplands (higher uplands falling to the east coast) in the northern catchments, centrally located catchments are in Macquarie Upland province (mainly dissected plateaus on sub-horizontal resistant sandstones, mainly of the Sydney Basin) and Kosciuszkan Uplands (mountains and plateaus ranging from the highest point in Australia to the coast) for the southern catchments.

Most the study area falls within a temperate climatic zone (BOM., 2016), with a small portion of the catchments north of Port Macquarie to Byron Bay sitting in the sub-tropical climate zone, which extends into Queensland. Mean annual temperatures of $2.4^{\circ} \mathrm{C}$ to $25.8^{\circ} \mathrm{C}$ and rainfall average of $590 \mathrm{~mm}$ to $2344 \mathrm{~mm}$ span these climatic zones. 
Young et al., Modelling hydrological changes in Coastal catchments of New South Wales under future climate change

\section{METHODS AND DATA}

\subsection{Climate Projections (NARCliM GCM/RCM)}

The NARCliM simulations (Evans et al., 2014) used the Weather and Regional Forecasting (WRF) modelling system (Skamarock et al., 2008). All 12 ensemble members are used which consist of all combinations of four CGM and three RCM. For each combination of GCM and RCM, three time periods are simulated; current climate (1990-2009), near future (2020-2039) and far future (2060-2079), assuming a high emission scenario (A2). While the climate models produce a range of variables, only daily maximum temperature, daily minimum temperature, precipitation and evapotranspiration are required to drive the water balance model. Cell resolution of the NARCliM domain is at $10 \mathrm{~km}$, datum is WGS84 regular grid.

\subsection{Water balance model (PERFECT)}

The water balance model used daily time-series of NARCliM non-bias corrected rainfall and areal potential evapotranspiration (Morton, F.I., 1983, Fei et al., 2015) modelled by each GCM/RCM as inputs. Actual ET was calculated daily using areal potential ET and seasonal crop factors. Crop factors varied by landuse category and foliage protection cover (FPC). Higher FPCs mean higher crop factors. Using FPCs to split land use categories to account for different levels of tree cover was crucial to account for spatial variability of FPC with a single land use category.

Partitioning between surface flow and recharge is driven by soil properties and topography for each $100 \mathrm{~m}$ cell within a NARCliM $10 \mathrm{~km}$ cell. Volumes of surface flow are governed by model parameters describing potential infiltration, antecedent soil water, surface and vegetative cover and slope. Volumes of recharge are controlled by parameters quantifying drainage rates through the soil profile, soil depth and slope.

The water balance model used in this study is the PERFECT model (Littleboy et. al., 1992). It was developed as a cropping systems model to predict the water balance (runoff, infiltration, soil evaporation, transpiration and recharge) for crop/fallow sequences. It has been previously applied to estimate water balance for a range of perennial pasture systems and tree water use in eastern Australia. Many examples of previous model validation in Eastern Australia are documented (e.g. Abbs et. al., 1998). A major strength of PERFECT is that it contains robust and well-tested algorithms, often based on proven water balance models developed by the United States Department of Agriculture.

PERFECT is a one-dimensional, daily time-step water balance model in that it predicts the water balance in a single column of soil. It does not predict lateral subsurface movement of water. Any excess soil water is assumed to move vertically as deep drainage to groundwater. Therefore, estimates of drainage from PERFECT are a combination of subsurface lateral flow and vertical drainage. To partition excess soil water moving laterally and vertically, the HYDRUS 2D model (Simunek et al., 1999) was applied to develop a generic model of lateral water movement (Rassam and Littleboy, 2003).

\subsection{Spatial datasets (Land use, Foliage Cover, Soil)}

PERFECT requires spatial data for land use, soil and slope. Dominant land use, soil type and slope vary significantly and spatially over the study area and are assumed as static through time. Although we

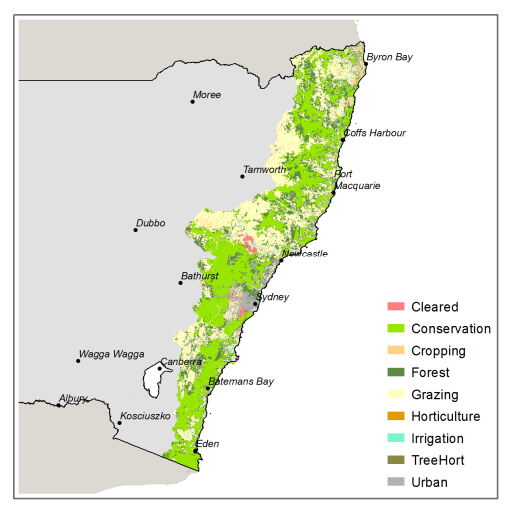

Figure 2. Dominant land use

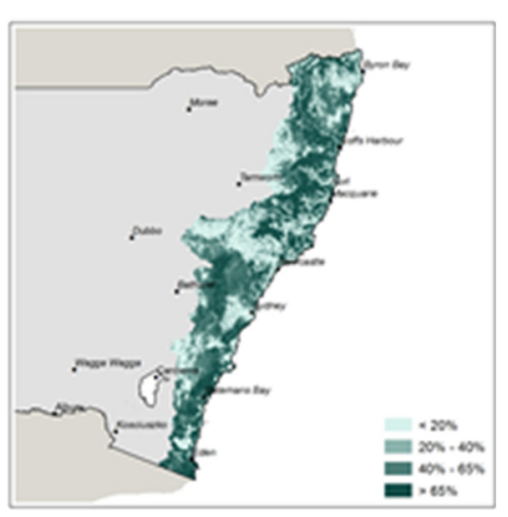

Figure 3. Foliage cover classes understand landuse varies through time, no time series landuse change data was available at the time of the modelling. Other inputs (NARCliM projections) do vary over time and space. In this study, the spatial resolution is $100 \mathrm{~m}$ for land use, soil, slope, lateral flow portioning (Rassam and Littleboy, 2003), and 10km for NARCliM grid.

\section{Land use and Foliage Protection Cover (FPC)}

Land use, land management and foliage cover have major effects on natural resources and water balance, with impacts on water infiltration, evapotranspiration, soil water holding capacity, nutrients, plants and animals. 
Young et al., Modelling hydrological changes in Coastal catchments of New South Wales under future climate change

Detailed land use mapping was derived from two NSW OEH corporate spatial data sets (NSW Land use v1 1:250 000, and Sydney 1:100 000 draft). The combined attributes, derived from NSW Land Use mapping program (LUMP), were allocated to nine simplified categories (cleared, conservation, cropping, forest, irrigation, horticulture, tree horticulture, urban) that better reflect hydrological response (Figure 2).

To improve spatial variability within the land use categories, foliage projected cover derived from the NSW Woody Vegetation \& FPC 2011 State-wide dataset, was categorised to 4 classes $(<20 \%, 20 \%-40 \%, 40 \%$ $65 \%,>65 \%$ ) (Figure 3 ). The categorised FPC layer was intersected with the land use layer to create hydrological response units.

\section{Soil Types (Great Soil Group of NSW)}

The nature and conditions of the underlying soils (depth, type, texture, chemical composition, physical properties, available moisture content, hydraulic conductivity, and bulk density) all affect the water balance within a catchment.

Soil types across the coastal catchments have been classified using a modified version of the Great Soil Groups (GSG) classification. It uses the best available soils and natural resource mapping coverage provided by the NSW Government.

The dominant soil type for each $100 \mathrm{~m}$ cell within the study area was determined (Figure 4). Soil hydraulic properties (water content, wilting point, field capacity, saturation, and hydraulic conductivity) for each GSG as compiled by (Littleboy et. al., 2003, 2009) were used to define soil hydraulic parameters. These parameters are input files to PERFECT model.

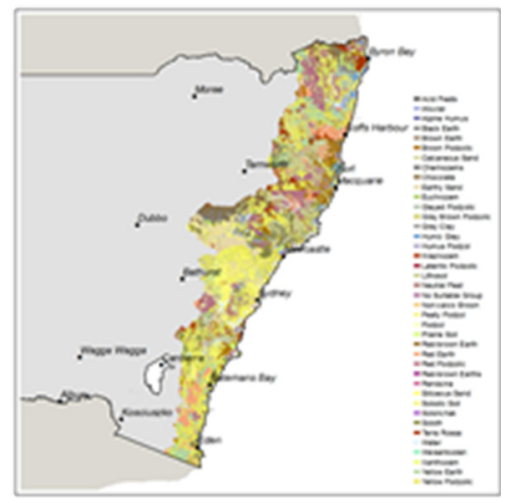

Figure 4. Dominant soil type

\section{Lateral Flow Partitioning Coefficient (Rh)}

Mean slope for each 100m cell was calculated from SRTM 30m resolution Digital Elevation Model (Shuttle DEM) and values for lateral flow partitioning coefficient (Rassam and Littleboy, 2003) were calculated.

\section{Modelling Environment (Python 2.7)}

Modelling was performed using a Python based system, backed by the core PERFECT water balance model, implemented in FORTRAN and compiled to executable (exe) format. The Python software managed the various spatial and temporal data inputs, and pre-processed this data for input to the point based PERFECT model, before assembling the outputs into spatial and aggregate output files as ESRI raster based format. At its core, the system manages unique 'scenarios', which describe a set of PERFECT model runs based on three key information sources for the area of interest; climate, soil and land use/foliage cover inputs. The intersection of these three information sources identifies a unique spatial area and determines the corresponding PERFECT model inputs and parameters required for the unit to be modelled. To minimise run times, only the unique combinations of a $100 \mathrm{~m}$ land use and soil within a single $10 \mathrm{~km}$ NARCliM cell were run.

The simulations presented in this report, the multi-step system was configured to:

- $\quad$ Read the post-processed NARCliM netCDFs containing daily data, convert to model input format.

- Index 10km NARCliM cell, and determine unique combinations of 100m drivers (land use, soil) and execute PERFECT for each unique driver combination.

- Compile modelled outputs as ESRI raster format for input to ArcGIS.

- Provide post processing of drainage partitioning. For each GCM/RCM scenario (annual and monthly), combine lateral and recharge to define total drainage and using lateral flow partitioning coefficient (Rassam and Littleboy, 2003), partition to groundwater recharge and surface runoff.

- Generate seasonal grids by combining each GCM/RCM scenario, months 12,1 and 2 for Dec, Jan, Feb (Summer), 3,4 and 5 for Mar, Apr, May (Autumn), 6,7 and 8 for Jun, Jul, Aug (Winter), 9,10 and 11 for Sept, Oct, Nov (Spring).

- Extract annual and seasonal means for each epoch (baseline 1990-2009, near-future 2020-2039, farfuture 2060-2079) as input csv for R script. R script to produce relevant graph based outputs of absolute change (Figure 7 and 10) 
Young et al., Modelling hydrological changes in Coastal catchments of New South Wales under future climate change

\section{RESULTS}

\subsection{Changes in Surface Runoff}

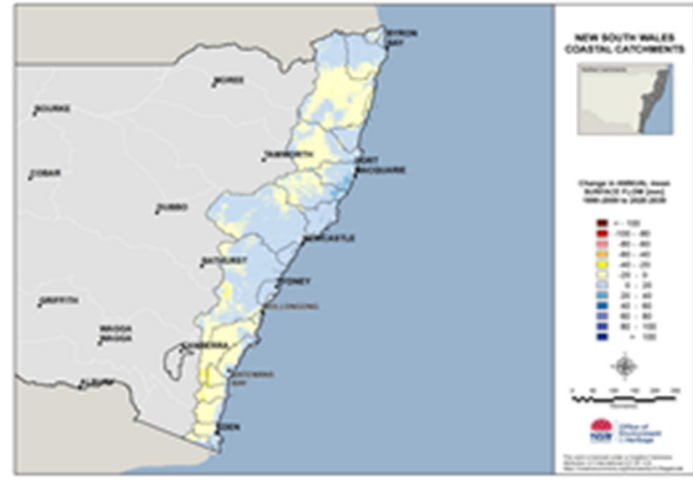

Figure 5. Annual mean change in surface runoff 1990-2009 to 2020-2039

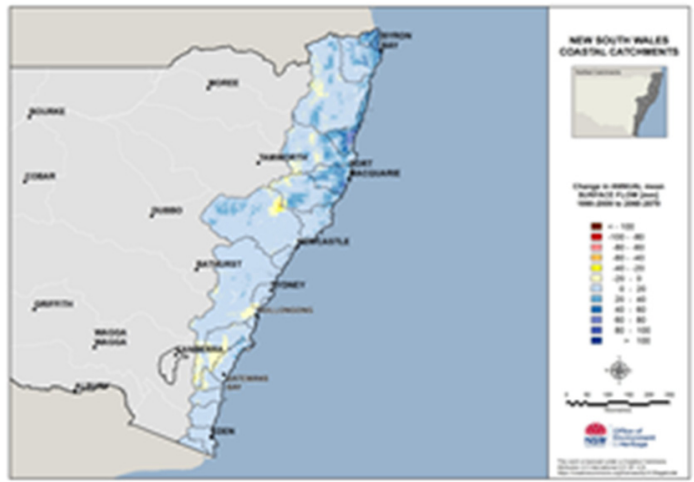

Figure 6. Annual mean change in surface runoff 1990-2009 to 2060-2079

Across much of the study area, surface runoff $(\mathrm{mm} / \mathrm{yr}$.) is likely to increase in both near and far future scenarios based on the multi-model mean of simulations. However, there is a large spread across different model simulations (Figure 7). The largest increases are projected in the northern catchments (Manning, Hastings, Macleay River and Bellinger) north of Newcastle and Port Macquarie and along coastal fringes to catchments around Byron Bay (Tweed, Richmond and Brunswick). Reductions of greater than 20mm/yr. in surface runoff are projected for higher elevation regions in the south of the State.

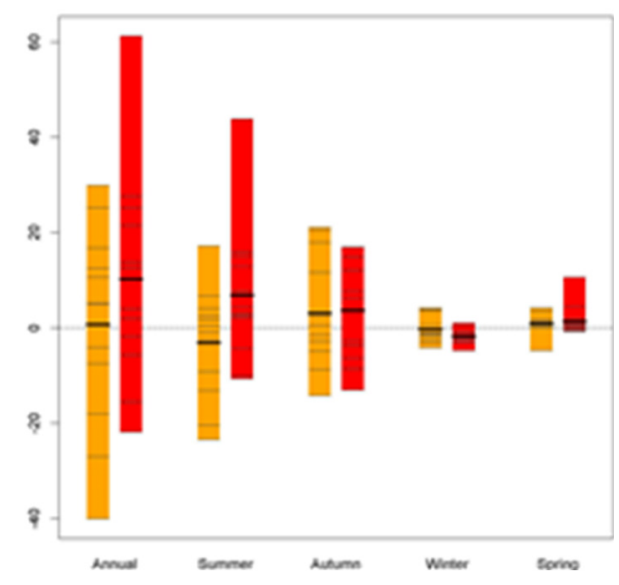

Figure 7. Absolute change surface runoff Orange: Near future, Red: Far future

As noted above, there is a spread between different models. This can be seen in the range of projections for the coastal catchments annual mean surface flow, ranging from a decrease (drying) of $-40.1 \mathrm{~mm} / \mathrm{yr}$. to an increase (wetting) of $+29.9 \mathrm{~mm} / \mathrm{yr}$. for the near-future 2020-2039 (Figure 5 and 7). There is also a large range from drying to wetting $(-21.8 \mathrm{~mm} / \mathrm{yr}$. to $+61.2 \mathrm{~mm} / \mathrm{yr}$.) for the far-future 2060-2079 (Figure 6 and 8).

Mean seasonal projections for the near-future 2020-2039 also show a range that includes both increases and decreases for summer $(-23.4$ to $+17.2 \mathrm{~mm})$, autumn $(-14.2$ to $+21.1 \mathrm{~mm})$, winter ( -4.1 to $+4.2 \mathrm{~mm})$, and spring $(-4.7$ to $+4.2 \mathrm{~mm})$. For farfuture 2060-2079 the changes are: summer $(-10.7$ to $+43.9 \mathrm{~mm})$, autumn $(-13.1$ to $+17.0 \mathrm{~mm})$, winter $(-4.8$ to $+1.1 \mathrm{~mm})$, and spring $(-0.8$ to $+10.7 \mathrm{~mm})$ (Figure 7$)$. The largest change evident is the increase in the far future period than the near future period for summer.

For near future (2020-2039), the NARCliM simulations using CCCMA3.1 GCM $\backslash R C M$ as hosts all tend to project an increase in annual surface flow (wetting), whereas those using CSIRO-MK3.0 project a decrease in surface flow (drying). For the far future (2060-2079), 8 of the 12 NARCliM simulations project an increase in surface runoff, and 4 show no change or a decrease in surface runoff. The largest range between models on a seasonal basis are present during summer and autumn periods.

\subsection{Changes in Recharge}

For near-future 2020-2039, less recharge is projected across much of the coastal area based on the multimodel mean of the 12 simulations, especially in the south and north along the Great Dividing Range (Figure 8). For some areas, a slight projected increase in recharge occurs but these increases are relatively small. In the far-future 2060-2079 (Figure 9), recharge is projected to increase across many parts of east coast catchments. Areas of highest increase, tend to be within the northern catchments, along the coastal fringes north of Newcastle through to Bryon Bay. Considerably less recharge is projected in the higher to alpine range areas for both near and far future scenarios. 
Young et al., Modelling hydrological changes in Coastal catchments of New South Wales under future climate change

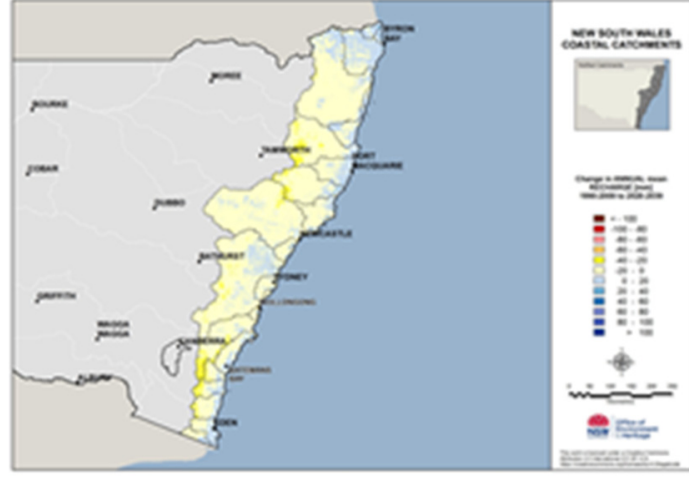

Figure 8. Annual mean change in recharge 1990-2009 to 2020-2039

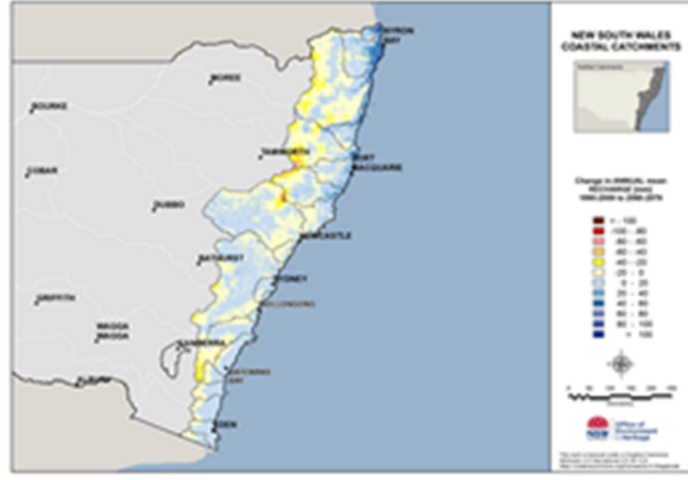

Figure 9. Annual mean change in recharge 1990-2009 to 2060-2079

However, as for surface runoff this multi-model mean is the mean of a large model range. Projections for the coastal catchments annual mean recharge range from a decrease (drying) of $-51.5 \mathrm{~mm} / \mathrm{yr}$. to an increase (wetting) of $+21.7 \mathrm{~mm} / \mathrm{yr}$. for near-future 2020-2039 (Figure 8 and 10), and still span both drying and wetting scenarios (-41.9 to $+84.5 \mathrm{~mm} / \mathrm{yr}$.) for far-future $2060-2079$ (Figure 9 and 10).

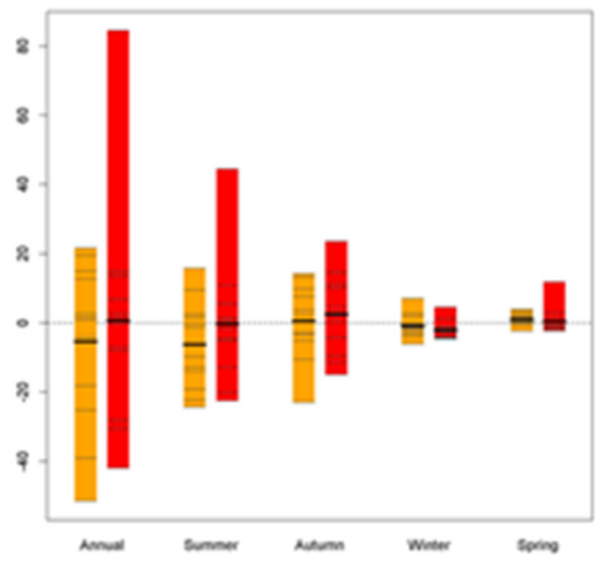

Figure 10. Absolute change recharge Orange: Near future, Red: Far future

Mean seasonal projections for the near-future 2020-2039 span both increases and decreases for summer $(-24.3$ to $+15.8 \mathrm{~mm})$, autumn $(-23.0$ to $+14.3 \mathrm{~mm})$, winter $(-6.1$ to $+7.1 \mathrm{~mm})$, and spring $(-2.3$ to $+4.0 \mathrm{~mm})$. For far-future $2060-2079$ the projections are: Summer $(-22.5$ to $+44.5 \mathrm{~mm})$, autumn $(-14.9$ to $+23.5 \mathrm{~mm})$, winter $(-4.6$ to $+4.6 \mathrm{~mm})$, and spring $(-2.4$ to $+11.9 \mathrm{~mm}$ ) (Figure ).

Based on annual mean recharge for the near-future, NARCliM simulations using MIROC3.2 and CCCMA3.1 as hosts all tend to project an increase in recharge (wetting), whereas simulations using CSIROMK3.0 and ECHAM5 as hosts tend to project a decrease in recharge (drying). For far-future 20602079,6 of the 12 NARCliM ensembles project an increase in recharge and 6 project a decrease to recharge. The largest spread between seasonal models are evident during summer and autumn periods.

\section{CONCLUSION}

Climate driven changes to surface runoff influence the availability of water resources, flows into natural and artificial water bodies, and the design and operation of rural and urban stormwater drainage systems. Secondary impacts such as salinity, erosion, water quality and aquatic biodiversity can also occur. Similarly, recharge is a vital component of the total water balance of a catchment and changes to recharge can influence the availability of groundwater resources and the volumes of base flow in streams. Secondary impacts such as salinity and water quality with subsequent impacts on aquatic biodiversity can also occur.

This study applied a 1-dimensional, daily time-step water balance for each grid cell using non-bias corrected rainfall and areal potential evapotranspiration (Morton, F.I., 1983) as inputs, Finer 100m resolution for land use, soil, FPC and topography (slope) were used to provide some spatial variability in results. The major limitation to the modelling is NARCliM data being available only at $10 \mathrm{~km}$ resolution.

In the near future simulations, projected changes in either runoff or recharge are generally small, with the multi-model mean projection showing a small reduction in mean annual runoff in southern areas of NSW, but a small increase in central and northern areas. However, there is a large model spread around this mean, with both increases and decreases projected by different simulations for the state-wide mean change.

Projected changes in the far future are larger than for near future, with more surface runoff and recharge projected across much of the State in the multi-model mean. However, there is also a wide spread between models for this period too, ranging from decrease to increase for the state-wide mean However, there is higher model agreement for the southern areas of NSW, which are projected to have less runoff and recharge. 
Young et al., Modelling hydrological changes in Coastal catchments of New South Wales under future climate change

Across most of the coastal catchments, higher runoff and recharge in the summer, autumn and spring months is projected due to higher autumn rainfall in many NARCliM projections (but not all). In southern parts of the State, there is higher model agreement for a marked drying during spring months resulting in less spring runoff and recharge.

\section{ACKNOWLEDGEMENTS}

The authors acknowledge Fei Ji, Terry Koen, Gregory Summerell, Jonathon Gray and Mark Young, for their on-going support, provision of datasets, quality assurance measures, document reviews, guidance and general knowledge of the subject matter.

\section{REFERENCES}

Abbs, K. and Littleboy, M. (1998). Recharge estimation for the Liverpool Plains. Australian Journal of Soil Research (36), 335-357.

BOM (2006), Gridded Koppen classification, Australian Bureau of Meteorology, accessed July 2017, http://www.bom.gov.au/climate/averages/climatology/gridded-datainfo/metadata/md koppen classification.shtml

Evans, JP. et al. (2014). Design of a regional climate modelling projection ensemble experiment - NARCliM. Geoscientific Model Development (7), 621-629, doi:10.5194/gmd-7-621-2014.

Fei, J., Littleboy, M., Rahman, J. and Young, J. (2015), Morton's Areal Evapotranspiration Study Design and Methods (in Draft), NSW Office Environment and Heritage Internal document.

IPCC (2001). Linking climate change and water resources: impacts and responses. Technical paper http://www.ipcc.ch/pdf/technical-papers/ccw/chapter3.pdf

Littleboy, M. et al., (1992). Impact of soil erosion on production in cropping systems. Development and validation of a simulation model. Australian Journal of Soil Research (30), 757-774.

Littleboy, M. et al., (2003). Applying unsaturated zone modelling to develop recharge maps for the MurrayDarling Basin in New South Wales, Australia. Proceedings International Congress on Modelling and Simulation, 14-17 July 2003, Townsville. Modelling and Simulation Society of Australia and New Zealand.

Littleboy, M., Sayers, J. and Dela-Cruz, J. (2009). Hydrological modelling of coastal catchments in New South Wales. Proceedings International Congress on Modelling and Simulation, 13-17 July 2009, Cairns.

Morton, F.I. (1983). Operational estimates of areal evapotranspiration and their significance to the science and practice of hydrology. Journal of Hydrology, 66, 1-76.

Pain, C., Gregory, L., Wilson, P. and McKenzie, N. (2011) The physiographic regions of Australia Explanatory notes 2011. Australian Collaborative Land Evaluation Program and National Committee on Soil and Terrain. http://www.clw.csiro.au/aclep/documents/PhysiographicRegions_2011.pdf

Rassam, D. and Littleboy, M. (2003). Identifying the Lateral Component of Drainage Flux in Hill Slopes. Proceedings International Congress on Modelling and Simulation, 14-17 July 2003, Townsville. Modelling and Simulation Society of Australia and New Zealand.

Simunek, J., Sejna, M. and van Genuchten, M. Th. (1999). The HYDRUS-2D software package for simulating two-dimensional movement of water, heat, and multiple solutes in variably saturated media. Version 2.0, IGWMC - TPS - 53, International Ground Water Modelling Centre, Colorado School of Mines, Golden, Colorado, 251pp., 1999.

Skamarock, W.C., Klemp, J.B., Dudhia, J., Gill, D.O., Barker, D.M., Duda, M.G., Huang, X.Y., Wang, W. and Powers, J.G. (2008). A Description of the Advanced Research WRF Version 3, NCAR Technical Note, NCAR, Boulder, CO, USA. 